\title{
医学と医療の最前線
}

\section{Anorexia nervosaの治療}

\author{
末松 弘行
}

\begin{abstract}
要 旨
Anorexia nervosaの定義について述べた上で，そのさまざまな治療法を紹介する。

本症の患者は，自分では病気と思っていないことがあるので，治療への動機付けがまずテー マになる，次に，外来加入入院治潦にするのはどのような状況の時かとか，専門家への引継ざ なども問題になる。本拝の治療は，心身両面から行うべきであるが，一応身体的な治療法と心 理的な治療法に二分される。身体的治療法としては, 薬物療法, 食事療法, 経鼻腔栄養, 経中 心静脈高力ロリ一輸液などと，無月経の治療がある。心理的治療法としては，一般心理療法， 㻴境調整, 行動療法, 芸術療法, 家族療法などがある。本誌は内科学会誌であるので,これら の中で，身体的治療法についてはやや詳しく解説し，心理的治療法は重点的にその概略を述べ b.
\end{abstract}

(日内会誌 $86: 856 \sim 861,1997$ )

Key words：神释性食欲不振拝，神経性過食症，認知行動潦法

\section{Anorexia nervosaとは}

内科学会用語集では, anorexia nervosa（以下 $\mathrm{AN}$ と略す)は「神経性食欲不振症」となっている。 その典型例は，若い女性でやせ願望からほとんど 食心゙なくなり，著しくやせて無月経などの症状を 伴うものである。アメリカ精神医学会の診断基準 (DSM-IV, Diagnostic and Statistical Mannual of Mental Disorders IVth Edition) などもある が，わが国の陧生省研究班の診断基準は表 10 通 りである。備考として，各項についての詳細な解 説があるので，一度これに目を通してよく理解し ておくと，後はまとめられた6 項目だけで診断で きる。

この第 2 項目の上うに, 食べない代かりでなく， 経過中には大食（過食）になることがある。これ が主となると神経性過食症 (bulimia nervosa，以 下BNと略す)といわれる。まれには過食のみの症

すえまつひろゆき：東京共済病院心療内科
例も西るが，その大半は不食（拒食）の後に反動 として起こる，過食してもやせ願望があるので， 指を口に突きこんで自己嘔吐するか，下剤や利尿 剤を乱用してやせていることが多い，拒食と過食 を繰り返す症例もある。したがってANとBNは， 相互移行的・重複的な病態である。両者を一括し て攝食障害 (eating disorders) という。本稿は 「ANの治蟟」が主題であるが, BNの治療にも一部 触れる。

\section{2. 治療への導入 (動機付け $)^{1)}$}

一般病の患者は, 治療を受けたいと思って受診 するところが，ANの患者は，やせることが目的 であるので，自分が病気であるとは思っていない ことが多い.自らでなく家族に連れられて受診し てくる，そこで当初は，治療への動機付けがテ一 マになる。

身体的にまだゆとりのある状態ならば，まず外 来で, 患者のいうことを傾聴し, 受容的に対応し て，医師患者関係をよくするように努める。 
表 1．神経性食欲不振症の竛断基蕉(厚生省特定疾㭧・神経性食欲不振症調查研究班)（1990）

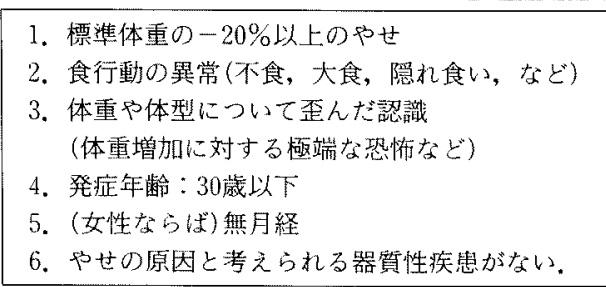

(備考) 1，2，3，5は既往歴を含拀。(例えば，一20\%以上の やせがかつてあれば，現在はそうでなくても基準虐満たすとす る.) 6 項目す心゙てを満たさないものは, 疑䛦例として経過観察 する.

1. ある時期に始まり，3力月以上持続。典型例は一 $25 \%$ 以上やせている。 $-20 \%$ は一応の目安である。(他の条項をすべ て满たしていれば, 初期のケースなどでは, 一-20\%に達してなくてもよい.)アメリカ精神医学会の基準(DSM-III-R) ではー15\%以上としている。標準体重は15藏以上では身長により算定(例：平田の方法)するが, 15藏以下では実測値 (例：日比の表)により求める。

2.食べないばかりでなく, 経過中には大食になることが多い，大食には，しばしば自己誘発性嘔昍や下痢・利屎剂乱用 を伴う。その他，食物の貯蔵，盗食などがみられる。また，過度に活動する傾向を伴うことが多い，

3.極端なやせ願望，ボディイメージの障害(例えば，ひどくやせていてもこれでよいと考元たり，肥っていると感じた り，下腹や足など体のある部分がひどく肥っていると信じたりすること)などを含む。これらの点では病的とは思っ ていないことが多い。この項は，自分の希望する体重について問影したり，低体重を維持しょうとする患者の言動に 着目すると明らかになることがある。

4.まれに30歳を超える。ほとんどは25歳以下で思春期に多い.

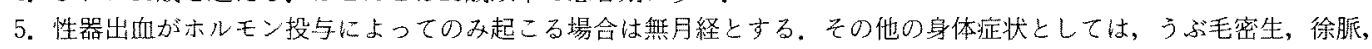
便秘，低血圧，低体温，浮腫などを伴うことがある。ときに男性例がある。

6. 精神分裂病による奇異な拒食, うつ病による食欲不振, 単なる心因反応(身内の死亡など)による一時的な掑食低下な どを鑑別する。

患者は「治療なんか必要ない」と思う気持と, 同時に「このままではどうにもならない（治した い)」という気持が共存している，そこで，後者の 気持が高まるように㗢きかけ，それを待つのであ る.そのためには，内科的な検査をすすめて，基 礎代謝率, 血中 $\mathrm{T}_{3}$ 值, 白血球数, 総蛋白值の低下 や成長ホルモン值, 肝酵素值, 永素公素值, 総コ レステロール值の上昇などの異常值を示し治療が 必要な状態であることを知らせて,「やりたいこと がたくさんあるようだが，体力が続くかどうか， 寝たきりになってしまわないかと心配だ」と治療 者の判断を伝える。また，不食ややせの背後にあっ て患者が困っているテーマ,たとえ沿，対人関係 などの話ができるようになると治療を受けたいと いう気持ができる。このようにして，心身両面で， 「他の人と同じように,何でもできるようになりた い」ことを確認して治療へのmotivationをつけ る.

\section{3. 外来か入院か}

身体的ならびに心理的な情報をあつめながら，
外来治療でよいか，入院が必要かを判断する。

Pierlootら ${ }^{2}$ は入院のクライテリアとして

(1) 標準体重に対して25\%以上のやせ

(2) 虽吐や下剂乱用による代謝障害がある。

(3) 自殺企画がある。

(4) 家族内での人間関係が悪い.

(5) 失敗した治療歴がある。

また, Brotmanら ${ }^{3 /}$ は, 以上の条件をさらに厳密 にして, 次の項目をあげている。

(1) 標準体重に対して $30 \%$ 以上のやせが，3 カ月 以上続く.

(2) 重篤な代謝障害（脈拍 $<40 /$ 分，体温

$<36^{\circ} \mathrm{C}$, 収縮期血压 $<70 \mathrm{mmHg}$, 血中 $\mathrm{K}<2.5$ $\mathrm{mEq} / l$, 血中BUN $>30 \mathrm{mg} / \mathrm{dl}$ )

(3) 重篤なうつ状態や自殺企画

(4) 澈しい過食傾向

(5) 明らかな精神病

(6) 家族環境の悪已

しかし，患者がかなりの低体重であっても，慢 性的にそうなっていて，このところは減少がなく ほぼ一定の場合には，それなりに馿化状態にある 
ので，むやみに入院を強制せずに，外来で治療関 係を保ちつつ，入院に対する動機づけをして，患 者本人も家族も，「やはり入院しなければ」という ことになってから入院という手䐓をふんだ方が， 結果がよい.

入院が必要なようなケースは，専門家にコンサ ルテーションするか，あるいは治療をゆだ极た方 がよいかもしれない.

入院すると以下に述べるような，専門的な治療 をすることになる。

\section{4. $\mathrm{AN} の$ 治療概説}

ANの治療は一般に困難とさ㧈て扔り，特効的 な一つの治療法があるわけではない。そこで，さ まざまの治療法が行われているが，それらは，身 体的な治療法と心理的な治療法に大きく二分され る.しかし，身体的な治療加入って身体的によ くなると，心理的にも改善される。また，強力な 心理療法加始めて心理的によくなると，食べる ようになって体重が増加し月経が再開する症例も ある、このように，本症は心身相関がみられる病 態である。そして，一般臨床においては，身体的 治療法と心理的治療法とを同時に組合せて行われ ている，つまり，身体的，心理的と便宜的にさし あたり分けたということになる。

本誌は内科学会誌であるので，身体的治療につ いてやや詳述し，心理的治療法については重点的
に概略を述べ，詳細は成書视にゆずる。

\section{5. 身体的治療法}

表 2 の礼した。

\section{1）薬物療法}

一般的には，スルピリド（ドグマチール，アビ リット)を150〜 300 $\mathrm{mg} /$ 日投与する.スルピリドに はさまざまな作用が考光られる。提食についての 異常な思考障害を改善するかもしれないし，視床 下部の食欲中枢に働きかける可能性も西る。また， 抗うつ作用もある。いずれにしてもスルピリドで よくなるケースがある。

次に，性格が硬い症例に心理療法の前手段とし て，クロルプロマジン (ウィンタミン，コントミ ン) $37.5 \sim 75 \mathrm{mg} /$ 日とか, チオリダジン(メレリル) 30 60 mg/日を用いる.あるい注，医師・患者関係 をよくするための補助手段となることもある。

プロマゼパム（レキソタン・セニラン）は，強 迫症状に有効であるとされている。一方，摂食障 害の性格として強迫傾向があり，そ扎が症状形成 に関与していることがある。この場合には，抗不 安薬が積極的に有効になる可能性がある。私共の 症例5で，「食事の前に，今日食べたものを 3 回思 い出して、扔新りしてからでないと食べられない」 という強迫症状のために，ほとんど食べられず， 体重が22kg（144cm）であった症例に，ブロマゼ パムを投与したところ，食べられるようになり，

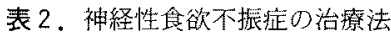

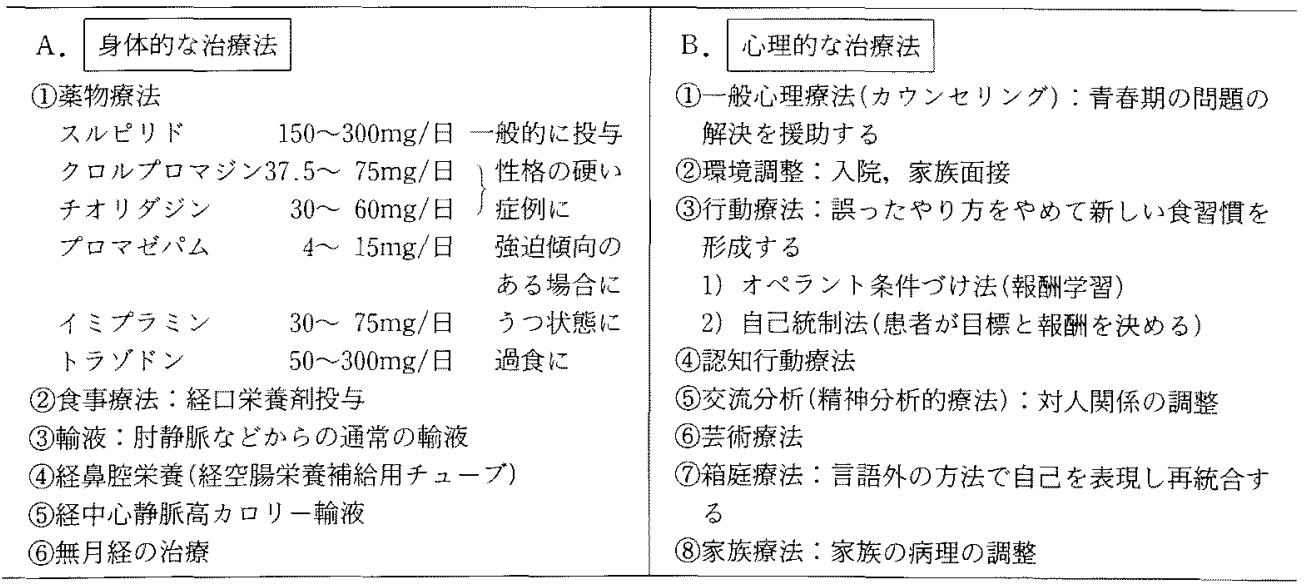


体重の増加が認められた。

過食するとよく落ち込んでうつになる症例があ る。このような時には，イミプラミン(トフラニー ル）を30〜 75mg/日投与する。 セロトニン再吸取 阻止型の抗うつ威のトラゾドン（レスリン，デジ レル）などが，アメリカで過食に有効であるとの 報告があり，わが国でも，この系統のいくつかの 薬品について治験が行われている。しかし，薬効 よりも，患者の生活上の問題の方が経過により関 わっているようである。たとえば，旅行に行った 時はよくて，気のす寸まない縁談話がある時には， いくら薬を飲んでもよくない゙!

\section{2）食事療法}

食事は，始めから大量配瞨しても食べないので， まず1000kcal/日くらいから始めて，数週扔きに $200 \mathrm{kcal} /$ 日ずつ増量していく，米飯を食べない患 者にはパン食にしたり，油物が苦手な患者には配 慮する。基本食も糖尿病食や潰瘍食など，病院で 配膳可能なうちから選べるようにする。こうして, 著しく偏らない範囲で，いくらかの選択ができる 方がよい。

また，クリニミールやサスタジエンなどの経口 栄目凬を $100 〜 150 \mathrm{~g} /$ 日すす好ると，比較的抵抗な く受け入れ，中には喜んで捸取する症例もある。

\section{3）輸液}

本症の患者泳，食べないばかりでなく，水分も 㗄取せず，1日尿量が200 300 mlで，脱水状態に なり，血液は濃縮し，血清 $\mathrm{Na}$ 值がみかけ上，上昇 する例もある。

この上うな症例では，まず，末梋血管からの点 滴加始好る。

\section{4) 経鼻腔栄養}

重症であり，しかも経口的な提取をほとんどし ない場合には，まず経鼻曌栄養を提案して，それ ほど苦痛ではないことを説明して納得を得てか ら，慣れたナースが赤ん坊にミルタをあげるよう なふうに行うと受け入れられる。経口栄養剤を 100 $\mathrm{ml} /$ 日ぐらいの少量加ら始めて，500 $\mathrm{ml} /$ 日程度ま で徐々に増量する，重篤な症例では，薄めてより 少量から慎重に始める.

「胃が張るから食べられない」という心気的な
患者には，細い十二指腸まではいる経空腸栄養補 給用チューブを用いる。これは持続的に㨂入して おいたままで，経口摃食も可能である。

経鼻腔栄養も，ただ肥らせればよいという考え 加ら強行すると，医師に対する恐怖や嫌悪感をい だかせたり，萎縮してしまうことがあるので注意 を要寸る。

\section{5）経中心静脈高カロリ一輸液}

近年では，よく経中心静脈高カロリ一輸液 (intra-venous hyperalimentation以下IVHと略 す)を行う。熊原ら”は，入院時すでに極度の低栄 養状態に宿り，生命の危機にさらされている場合 や，入院後一定期間管理していても改善傾向を認 めず，むしろ体重が減少する例に対してIVHを施 行している.

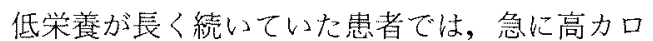
リ一輸液をすると, 旰機能の異常が起ったり, 浮 腫をきたすことがあるので，始めの数日は，フィ ジオゾール 3 号などの維持液を流す。次いで，バ レメンタールなどの高エネルギ一輸液を量として は40 50 ml $/ \mathrm{kg} /$ 日, 投与カロリーとしては25〜30 $\mathrm{kcal} / \mathrm{kg} /$ 日上り次第飞尔やして50〜60kcal $/ \mathrm{kg} /$ 日くらい投与する。

この場合も，ただ栄䓹を入れればよいという考 えで強引に行うと, 液をこっそり捨てたり, 留置 カテーテルを引き报いてしまったりすることがあ るので,心理療法と並行して行うことが望ましい． 熊原らもそのような配慮をしているが，Maloney $ら^{81}$ は, 週 2 回の心理療法と週 1 回の家族療法を 行っている。

Maloneyらは 4 人の患者に平均 25 日IVHを行 い， $5 \sim 12.8 \mathrm{~kg}$ (平均 $8.5 \mathrm{~kg}$ ) の体重增加をみてい 万。熊原らは，他の方法では体重が増加しなかっ たう例抢よび低血糖のため意識レベルの低下した 1 例に対してIVHを施行し， 1 週間に $1 \mathrm{~kg}$ 程度の 体重増加を認めたという。

体重が増加すると, Maloneyらの症例では心理 的㶤も好転し, 気分や病気についての認知, 社交 性などの改善がみられた。

もちろん，IVHでは敗血症，血栓症，気胸，電 解質異常などの合併症に注意すべきである。また， 
経口捸取食の量を徐々に増加させていって, 食べ ることを再学習させ, 輸液のカロリ一を減らし, 最後には, 経口のみに切り替える操作が必要であ る.

\section{6）無月経の治療}

無月経の治療は，体重が標準体重の $80 \%$ 以上に 回復し，女性として世に出て行こうとする気持の 上での準備ができ上ったうえで行う方がよい。

\section{6. 心理的な治療法}

表 2 のに示した．基本的には診察 (面接)に扔 ける一般心理療法である. 青春期の諸問題の解決 を援助するのであるが，一般医が時間的に困難な らば臨床心理士とのチ一ム医療が望ましい.この 際，環境調整も大切で，人間関係ことに家族関係 の調整のために，母親などとよく面接する.

現在,最も注目されているのは行動療法である。 これは，誤ったやり方をやめて新しい食習慣を形 成する方法である。その中のオぺラント条件づけ 法 (報酬学習) は，図の上うに，患者が食べたり 体重が増加したりすると報酬を与えて，食べると いう適応行動を強化するのである.報酬としては， 患者が活動を好むという特性を考えて外出，外泊 などを用いる，たとえば，図のように34kgになる と外出 1 時間, $36 \mathrm{~kg}$ になると外泊を許可するので ある.この体重増加の目標と，それが達成された 時の報酬の内容を，すべて患者が自分で決めて行 うのを自己強化法というがこの方が効果をあげや すい. しかし，増加した体重を患者が受け容れら

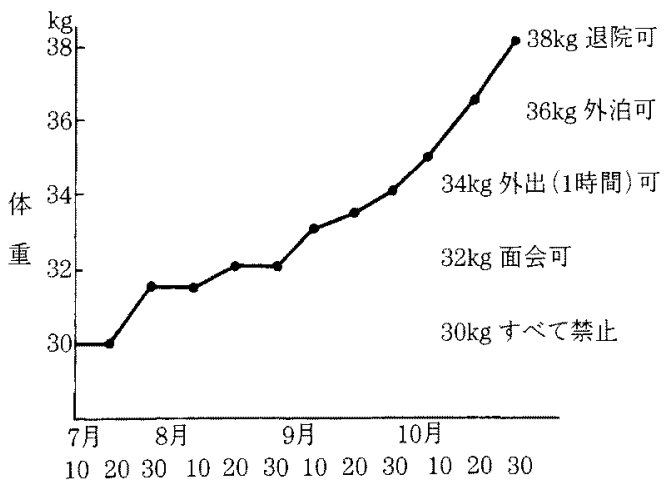

図、揁食傽害の行動潦法（オペラント条件づけ法）
表 3、神経性食欲不振症の転㛿

\begin{tabular}{c|c|c|c|c|c}
\hline 転帰 & 治崅 & 埾快 & 不変 & 死亡 & 計 \\
\hline 例数 & $\begin{array}{c}186 \\
(44 \%)\end{array}$ & $\begin{array}{c}162 \\
(39 \%)\end{array}$ & $\begin{array}{c}58 \\
(14 \%)\end{array}$ & $\begin{array}{c}12 \\
(3 \%)\end{array}$ & 418 \\
\hline
\end{tabular}

れるように，「健康な体重とは」といった認知の修 正を行わないと, 数力月で元の木阿弥になってし まう。そこで, この認知療法を組み合せた, 認知 行動療法が本症の治療の世界的な本流となってい 尚.

有効とされている治療法のもう1つは家族療法

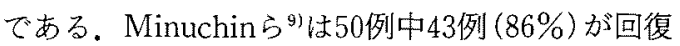
したと報告している。

その他，精神分析をやさしくした交流分析で， 対人関係を調整したり, 絵画療法などの芸術療法 を併用したりする。箱庭療法は言語外の方法で治 療としてよく活用されている。

\section{7. 転帰}

われわれの調査での転帰は表 3 の通りである。 半数くらいは割によい方向である。ことに若い症 例で早期に治療すると転㷌は良好である。しかし ながら，3\%は死亡している、スウェーデンの Theander ${ }^{10}$ は 92 症例を20年以上にわたって追っ ているが，12年間よくならなかったが，その後よ くなったという症例もあるとのことである。これ は, 患者にとっても家族にとっても，治療者にとっ ても，1つの光明である.

\section{文献}

1) 伊藤克人，他：神経性食欲不振症の治療計画。消 化器科 $4: 613,1986$.

2) Pierloot $R$, et al: An inpatient treatment program for anorexia nervosa patient. Acta Psychiat Scand 66: 1, 1982.

3) Brotman A, et al: Medical complications of eating disorders. Compr Psychiat $26: 258,1985$.

4）末松弘行，他編：神経性食思不振症. 医学書院， 東京, 1985.

5) Suematsu H, et al: Eating disorders and antianxiety agents. Asian Med J 34 : 593, 1991.

6) 末松弘行：過食症に対する Trazodone D効果に ついて，厚生省特定疾患神経性食欲不握症調查研 究偱, 平成 2 年度研究報告畫, p244.

7) 熊原雄一, 他：神経性食欲不振症の治療法。臨床 
科学 $18: 875,1982$.

8) Maloney MJ, et al: Treatment of severe weight loss in anorexia nervosa with hyperalimentation and psychotherapy. Am J Psychiat $137: 310,1980$.

9) Minuchin $\mathrm{S}$, et al: Psychosomatic families:
Anorexia nervosa in context. Harvard Univ Press, Cambrige, 1978.

10) Theander $S$ : Outcome and prognosis in anorexia nervosa and bulimia. J Psychiat Res 19: 493, 1985. 